\title{
Spirituality and Concept of 'Child' in Kokas Pedagogy for Children with Special Educational Needs
}

\author{
Csilla Imola, Székely ${ }^{1}$, \\ Recommended citation: \\ Székely, Cs. I. (2020). Spirituality and Concept of 'Child' in Kokas Pedagogy for Children with Special \\ Educational Needs. Central European Journal of Educational Research, 2(1), 10 - 21.
}

\begin{abstract}
Klára Kokas was a music teacher and music psychologist (1929-2010). Her method is based on music, motion and manual arts, therefore it can be defined as a form of reform pedagogy, otherwise it is called complex art pedagogy. The main elements and characteristics of Klára Kokas's pedagogy were revolutionary new ideas in the fields of personality development, and music education - compared to the practices of reform pedagogy trends in the 20th century Europe and the United States (Pukánszky-Németh, 1996). The main elements of this concept are music, dance improvisation, motion, imaginative stories, visual arts, painting and drawing. However, its most important component is the very specific and intimate relation, which connected her to children. This distinctive feature of the Kokas-method is hard to teach. Klára Kokas approached to people with problems, suffering and disabilities, especially to marginalized and disadvantaged children with utmost empathy. She struggled to develop the social-cognition skills and affectionate behavior of the handicapped children through her own invented musical method.Her writings reflected her relationship with God, namely the presence of Him which can be felt behind the scenes. His name was mostly unspoken, yet when she named Him, it was to reveal that God was always in her mind, like in her words and musical activities too.The goal of this paper is to search and frame that text corpus, which can outline the spirituality of Klára Kokas with the aim of drawing up her relationship with God and children - according to her publications, writings, essays, books, short-film compilations, movie archives and interviews (Kokas, 1992; 1999; 2002; 2007; 2012; 2013). The contours of her spirituality from her teachings, manuscripts and publications couldn't be attributed to any religious denomination. Also, to be presented are her notions about youth and teenage spirit and a unique relation with the world, her own students, the talents, the music and the holiness: the spirituality of Klára Kokas. The importance of beliefs and moral convictions in the art of education will be outlined.A single paragraph of about 150-200 words maximum. For research articles, abstracts should give a complete overview of the work. We encourage authors to use the following style of abstracts: background, methods, results and conclusion. The abstract should give an objective representation of the article.
\end{abstract}

Keywords: Klára Kokas, spirituality, complex art pedagogy and therapy, personality development.

\section{Introduction}

In my study I emphasize the aspects of the music teacher and music psychologist Klára Kokas's (1929-2010) spirituality and concept of 'child' based on her book entitled „Music Raises my Hands". This research is part of a greater critical investigation into the analysis of her publications which methodizes the Kokas-pedagogy in three main dimensions: her concept of God, man, and childhood.

${ }^{1}$ University of Debrecen, Debrecen, Hungary; szcsillaimola@gmail.com 
As a result of our research the education philosophy of her method will be conceptualized, which means the basis of the whole Kokas-concept. We will identify her educational goals, values, and the very specific relationship she had with children, also her beliefs of holistic education, and we will point out her place among the representatives of reform pedagogical trends.

According to Klára Kokas's world view and child-centered pedagogy, as a music teacher and music psychologist, she built her method on creativity, human and interpersonal relationships, childcentered approach, personality development and attention to others. These aspects are characteristic of the reform pedagogical methods - art pedagogical elements like music and dance- additional values of the Kokas method.

It is important to see that these views about children and childhood, which are dependent on the perception of the people of each era (Szabolcs, 1999. 64), are the majority opinions of educational researchers, teachers and other adults.

Kokas had the opportunity to present her musical-improvisational method not only in Hungary, but also abroad in the 1980's, so she had the chance to apply her methods and ideas on deaf and hard of hearing, disabled and special-needs children. These persons were received and included in her work teams with special care and empathy.

The Kokas educational concept can increase the chances of raising up underdeveloped, disadvantaged, disabled people. Their mates always helped them sympathetically, and complemented the deficiencies or insufficiencies of those participants who required special treatment. Children accept the unusual and different without any contempt or astonishment. This kind of education concurrently teaches empathy to able-bodied children.

As a recognition of her work and educational innovations, she received the Danish award in 1988, named Music Education for the Handicapped - in recognition of outstanding service on behalf of the handicapped (Deszpot, 2012. 18).

Klára Kokas wrote a lot about the spiritual characteristics of children and adults, while she emphasized the value of relationships. Not only can we read about her relation to God, but we can also feel His presence in her texts through her references to Biblical words and expressions. Based on these we can appreciate her spirituality.

We notice that Klára Kokas often used expressions, descriptions and names which reflected her concepts about God (holy, Creator of the Universe, Silence, Master), humankind and children, such as: their empathy, attention to others, relation to school, interpersonal relationships, acceptance, imagination, personal mission, spiritual presentation to others, self-expression, freedom, community, motion, tolerance towards people with disabilities. These comprise the foundation of the Kokas method.

I based my research on the book, "Music Raises my Hands", which was printed in 1992 by Akadémiai kiadó in Budapest. In this book we can read about Klára Kokas's personal views on educational theories, her memories and children's stories about their improvisational dances.

This book of hers will answer our research question, which is: how can Klára Kokas' concept of 'God' and the 'child' be drawn based on her book „Music Raises my Hands”?

\section{Data sources and aims of the research}

Klára Kokas's complex art pedagogy based on music, motion, visual arts and verbal narratives can be specified as reform pedagogy - so Kokas can be called a reform pedagogue.

\section{Aspects of the 'God' concept}

Religiosity versus spirituality - we have to determine the differences between these two (Tomcsányi et al., 2010), mentioning that they are indistinguishable. According to Pargament, an American religious psychologist, religion is a large collection of rituals, symbols and traditions, and spirituality is the seeking of the Sacred (Tomcsányi et al., 2010).

Burkhardt said, spirituality is a component of every individual and the search for God is determined by specific characteristics of people's personalities. Piedmont said, it is a basic dimension 
of the personality (Tomcsányi et al., 2010). So spirituality is a larger expression than religiosity, and refers to any kind of spiritual experiences or needs.

"Vergote intends to prove empirically that the Christian religion can be construed as the sum total of two anthropological impulses. One is the longing for the presence of God (mysticism), and the other is the (ethical or prophetic) desire for perfection (VERGOTE 1979)" (Tomcsányi, 2010).

The dimensions of the constitution and development of religion are:

- The psychodynamic-interpersonal dimension (the psychodynamic of the self-self relationship).

- The relational-interpersonal dimension (the dynamic of the self-Other relationship).

- The interpretative-hermeneutic dimension (the dynamic of the self-tradition relationship).

- The life-world dimension (the dynamic of the self-social world relationship). (Streib, 2001).

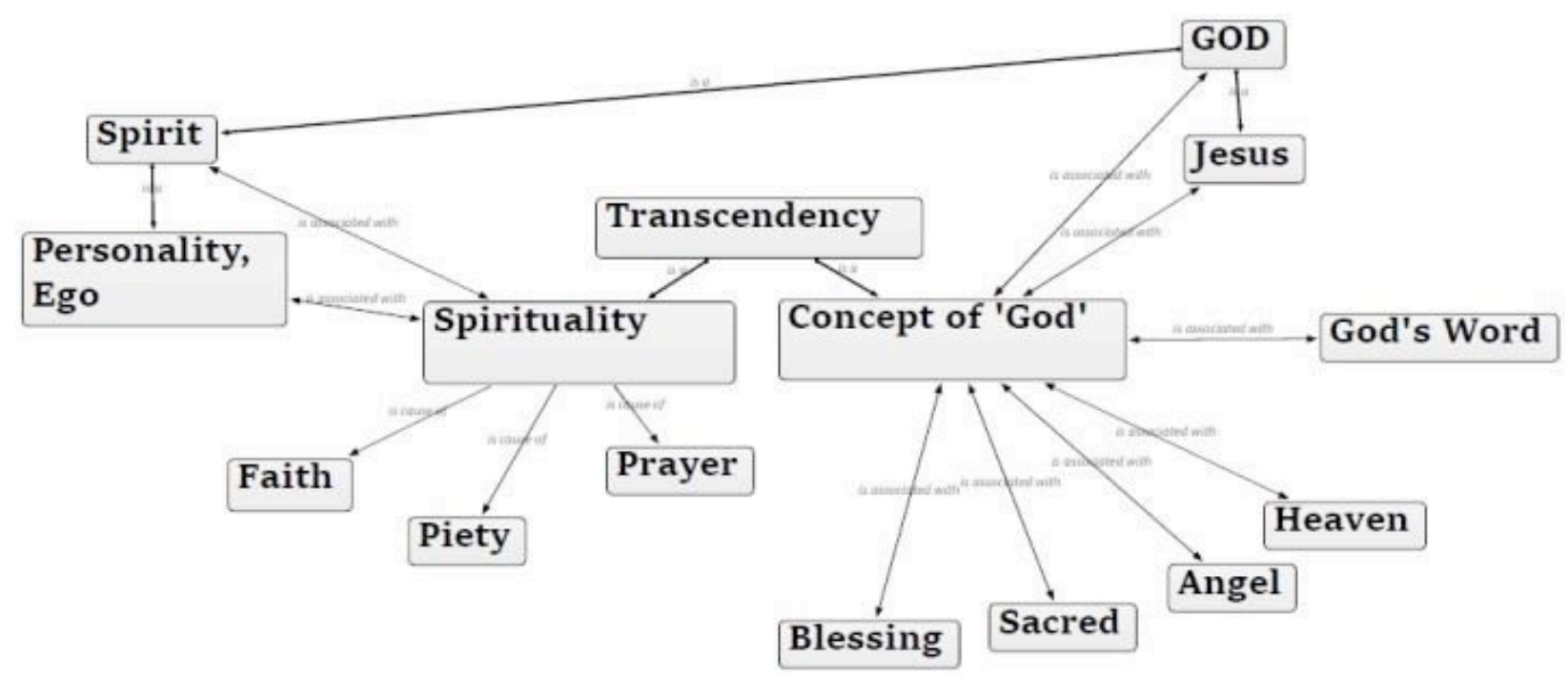

Figure 1. Spider diagram: Semantic aspects of Kokas's 'God' concept based on her book „Music Rises my Hands" (edited by the author)

Sorting Kokas's expressions into groups offers an easy way to think of these aspects:

About God: God's names and invocations

Religious representations of God: blessings, angels, sacred, holiness, heaven, sky

Spirituality: spirit, heart, creature, personality

Spiritual activities: prayer, faith, piety

Transcendence

\section{Overview of the history of educational philosophies and concepts}

Pedagogical theories can be grouped into three major sections according to the anthropological periods, says Ferenc Pálhegyi psychologist and marriage therapist, and there are three pedagogical approaches according to these groups:

pedagogy of forming the instincts

pedagogy of forming the behavior

and the humanistic pedagogy (Pálhegyi, 2011).

Theories and study of childhood and education have gone through many changes over the years. Beginning with the Spartan military education, the innocent child concept of the renaissance, Descartes's dualistic anthropology, Rousseau's moral pedagogy, the Christian sinful man concept, the behaviorist human concept, the alternative child view of the reform pedagogies, the communist 
human manner, and ending with the modern day creative child interpretation (ld. PukánszkyNémeth, 1996; Pukánszky, 2001).

See also „Children, family, death” by Philippe Ariés (1914-1986) French historian, former writer about history of childhood.

\section{The working method of the study}

Atlas.ti7, a qualitative text analyzing software, helped the research by identifying indicators. The next step was using codes, creating a specific text analysis concept, then determining the three dimensions of Klára Kokas's world view: her concept of 'God', 'humankind' and 'child'.

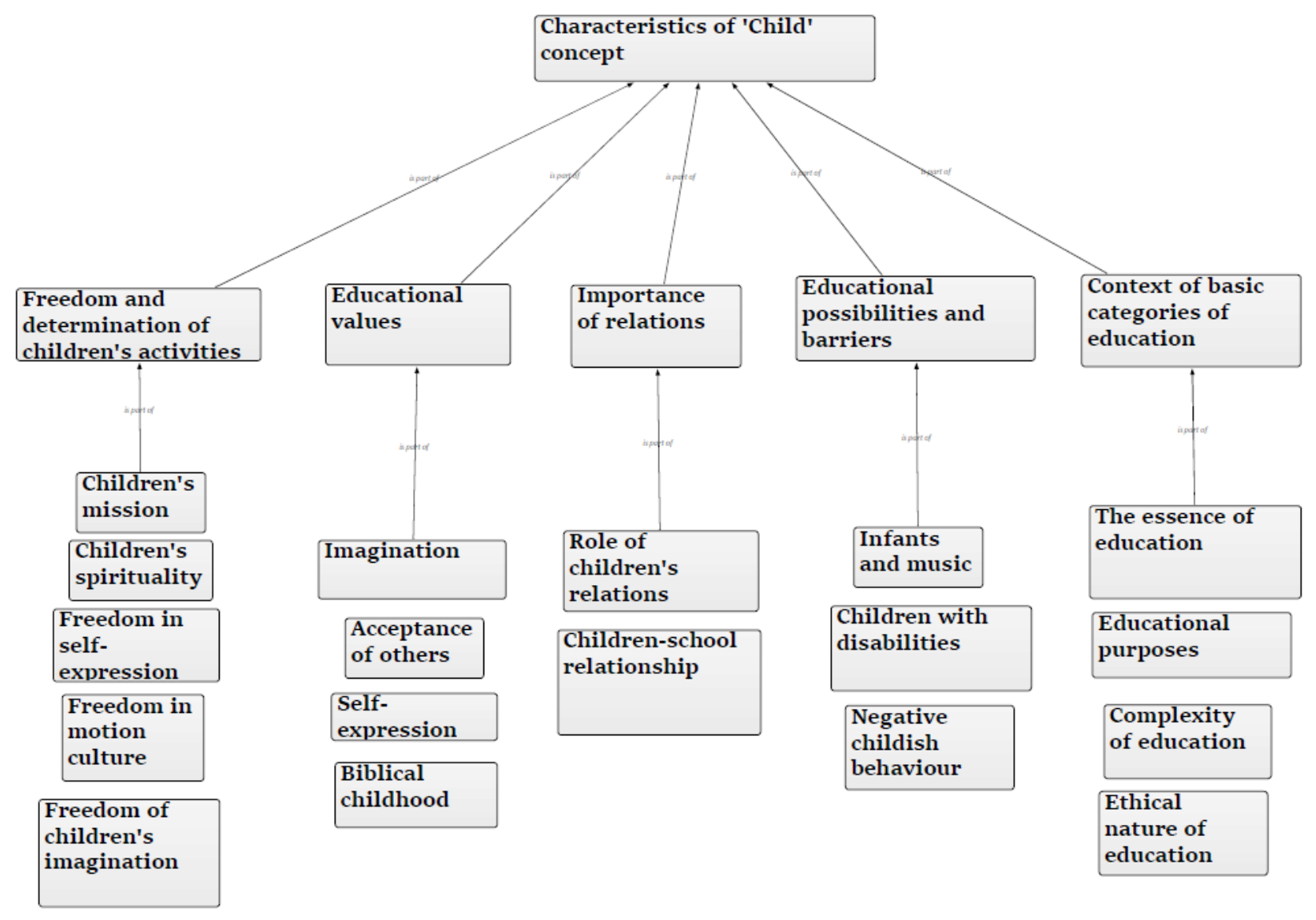

Figure 2. Categories of Kokas's educational theories (edited by the author)

\section{Characteristics of Kokas's 'child' concept according to her book, „Music Raises my Hands”}

As a research result, Kokas' 'child' concept is grouped into five main topics:

1. Freedom and determination of children's activities - existence of freedom, its borders, creating possibilities on Kokas' lessons

2. Educational values - basic formulas of children's spirituality: according to „Music Raises my Hands" Klára Kokas considered eternal human value exemplified by the following virtues: children's imagination, empathy, different artistic objects and the knowledge which comes from sincere and unspoiled childlike hearts. This artwork is the most authentic message, so, Kokas accepted them with great seriousness. She always listened to them from a Christian (gospel) aspect.

3. The importance of relationships and contact network $s$

4. Possibilities and barriers, special situations in Kokas' children's groups 
5. The context of the basic categories of education - the essence, purpose, complexity and ethical nature of education

The value perception of Klára Kokas emphasized the spiritual-psychological-esthetical virtues rather than the intellectual and material ones (see Bábosik, 2009). These values are manifestations of children, their creations and manual artworks, creativity, Christian thinking, social integration, community developmental attitudes.

We can notice that physical, cognitive and material values are missing from this list. Kokas' purpose was to nurture children's spiritual and imaginative powers, and to stimulate their inner harmony, personal creativity. She didn't pursue knowledge development or informational teaching. "Children are more at home in artistic fields (than adults), because imagination is their medium. As adults, we emerge from the fountain of our childhood" (Kokas, 1992). "Imagination, transformation in dance, poetry, magic and tales lead children to knowledge" (Kokas, 1992).

As an additional value Kokas interpreted her profession as a validation of Christian virtues in education - this is why we mention her accentuated faith when we speak about the Kokas-method. „The Master said: 'unless you become like little children, you will never enter the kingdom of heaven'. In what sense? With my grown-up students we work toward that together," (Kokas, 2002, Bible - Mat. 18,3).

Inclusive education is expanding in our days, and people with special needs are at its focus, just like in the case of the reform pedagogies. The Kokas-method can be placed among inclusive educational methods, because of its therapeutic aspects, and because Kokas accepted children with unusual behavior and other difficulties in her classes.

\section{Conclusion}

This study analyzes one book of Klára Kokas', „Music Raises my Hands”, through critical text interpretation to conceptualize her concept of 'God' and the 'child'.

Her aim was not only the skill development of her students through music, nor development of music literacy, but personality development which had therapeutic effects through a complex method of the integration of music, motion, and the arts. It included, at the same time, special education, development of self-esteem and self-knowledge, and relationships within the family. So, she connected the field of music and therapies with the strengthening of relationships to create an atmosphere of joy - this is why she named her foundation "Kokas Klára Agape Music Life-Joy Foundation".

The essence of her value system is education based on personal relations, spirituality, mutual acceptance, experiences, empathy, complete attention, creativity, and manual-movement-musical arts.

In conclusion we can identify the specific characteristics of the Kokas method, which are the Christian faith and spirituality added to the afore mentioned educational concepts and theories. This aspect gives her life's work special color.

\section{References}

1. Ariés, P. (1987). Gyermek, család, halál [Child, family, death]. Budapest: Gondolat.

2. Bábosik, Z. (2009). Értékközvetítés napjainkban [Valuation today]. Retrieved from http://ofi.hu/tudastar/ertekkozvetites

3. Biblia: Új fordítású revideált Biblia [New Translation of the Revised Bible]. Retrieved from http://abibliamindenkie.hu/

4. Buda, B. (2005). Csoportjelenségek a gyermek- és ifjúkorban; nevelési felhasználásuk [Group phenomena in childhood and adolescence; their educational use]. In: Balogh L. \& Tóth L. (edit.), Fejezetek a pedagógiai pszichológia köréböl [Chapters from the field of pedagogical psychology]. Budapest: Neumann Kht. Retrieved from http://mek.oszk.hu/04600/04669/html/balogh_pedpszich0015/balogh_pedpszich0015.html

5. Kokas, K. (1972). Képességfejlesztés zenei neveléssel [Skill development through music education]. Budapest: Zeneműkiadó.

6. Kokas, K. (1992). A zene felemeli kezeimet [Music raises my hands]. Budapest: Akadémiai Kiadó.

7. Kokas, K. (1999). Joy Through the Magic of Music. Budapest: Akkord zenei Kiadó. 
8. Kokas, K. (2002). A deszka galaktikája [The galaxy of planks]. Parlando, 2002/5. Retrieved from http://www.parlando.hu/Kokas1.htm

9. Kokas, K., Lájer, Jné., Furka, B. \& Kocsis, M. (2007). Öröm, büvös égi szikra. Multimédiás DVD-rom tanításaimról. [Joy Through the Magic of Music. A multimedia DVD-rom about my teachings]. Budapest: copyright edition.

10. Krippendorff, K. (1995). A tartalomelmezés módszertanának alapjai [Fundamentals of content analysis methodology]. Budapest: Balassi kiadó.

11. Marton-Dévényi, É. (2010). „Egy másik létformában - teljesen”. Nádi tündér [In another form of life wholly ". Reed fairy]. Fordulópont [Turning point], II/48. 65-80. http://www.fordulopont.hu/FP48_devenyi.pdf

12. Németh, A. (2002). A reformpedagógia gyermekképe A szent gyermek mítoszától a gyermeki öntevékenység funkcionális gyakorlatáig [The Child Image of Reform Pedagogy. From the Myth of the Holy Child to the Functional Practice of Child Self-Activity]. Iskolakultúra [School culture], 2002/3. Retrieved from http://epa.oszk.hu/00000/00011/00058/pdf/iskolakultura_EPA00011_2002_03_021-032.pdf

13. Pálhegyi, F. (2011). Örjárat az etika körül. Interjú [Patrol around ethics. Interview]. Retrieved from https://palhegyiferenc.wordpress.com/2011/10/16/palhegyi-ferenc-nevelesi-iranyzatok/

14. Pukánszky, B. (2001). A gyermekkor története [The history of childhood]. Budapest: Müszaki könyvkiadó.

15. Pukánszky, B., Németh, A. (1996). Neveléstörténet [History of education]. Budapest: Nemzeti Tankönyvkiadó Rt. Retrieved from http://mek.oszk.hu/01800/01893/html/04.htm\#Heading5

16. Robu, M. (2013). Az istenreprezentáció kognitív szempontú vizsgálata. Értekezés, kézirat [A cognitive study of God representation]. (Unpublished doctoral dissertation). University of Debrecen.

17. Streib, H. (2001). Faith Development Theory Revisited: The Religious Styles Perspective. The International Journal for the Psychology of Religion. 11(3), 143-158.

18. Szabolcs, É. (1999). Tartalomelemzés a gyermekkortörténet kutatásban. Gyeremkkép Magyarországon. 18681890 [Content analysis in childhood history research. Concept of child in Hungary. 1868-1890]. Budapest: Nemzeti Tankönyvkiadó.

19. Tomcsányi, T. (2010). Antoine Vergote, Founder of the Empirical and Psychoanalytical Approach in the Psychology of Religion. European Journal of Mental Health 5 (2010) 1, 45-58.

20. Tomcsányi, T., Ittzés, A., Horváth-Szabó, K., Martos, T., Szabó, T. (2010). A spiritualitás és a vallásosság kutatásának kulcskérdései és a Piedmont-féle Spiritualitási és Vallási Érzület Mérőskála [Key Issues in Research on Spirituality and Religiosity and Piedmont's Spirituality and Religious Sense Scale]. Psychiatria Hungarica, 2010/25 (2). 110-120.

(C) 2020 by the authors. Submitted for possible open access publication under the terms and conditions of the Creative Commons Attribution (CC BY) license (http://creativecommons.org/licenses/by/4.0/). 